\title{
Evaluation of Interest Rate Free in Indonesian Islamic Banking
}

\author{
Roikhan Mochamad Aziz ${ }^{1}$, Syahrul ${ }^{2}$ \\ ${ }^{1}$ Jakarta Islamic State University, Indonesia \\ ${ }^{2}$ Dynivy Centre, Indonesia \\ ${ }^{1}$ Roikhan.ma@uinjktac.id, ${ }^{2}$ pdsidip@gmail.com
}

\begin{abstract}
+
\section{Keywords:}

Islamic Banking Assets, $\mathrm{NPF}$,

SBIS.

\section{ABSTRACT}

The purpose of this study reviewed the analysis and discussion in a thesis entitled "Analysis of Effect of Non Performing Financing (NPF), assets of Islamic Banking and Bank Indonesia Certificates Sharia (SBIS) Financing Against Islamic Banking in Indonesia in 2010-2013". This research methodusing descriptive qualitative method in which these two methods are analyzed and explained by the subjective nature or in accordance with the object. The data used is qualitative data that comes from two sources, namely primary data and secondary data. Then the data is formulated and interpreted so neatly into one. The data collection is done by observation, interview, documentation, and literature. The results of this research are variable Non Performing Financing (NPF), assets of Islamic Banking and Bank Indonesia Certificates Sharia (SBIS) mempunai significant effect on the financing of Islamic banking in Indonesia.
\end{abstract}

\section{A. INTRODUCTION}

The economy of a country is an important aspect for the development of a country because its economy as well. Islamic banking is also included in one of the growing economy of the country of Indonesia. As is well known that Islamic banking is the only bank that did not undergo colaps during the monetary crisis. Islamic banks judged to have resistance to shocks of economic crisis. This is because the Islamic banking did not base its operations on the application of interest rates due to the high value of the interest rate is a factor inhibiting investment affect economic growth instability. Besides that, Islamic banking also requires the underlying assets in any transaction as a shield in the management of risk and forbids the sale or rental on something that is not owned by banning the practice of speculation in the financial system. Uniqueness is what proves that Islamic banking is not just an alternative to conventional banking, but the solution in rebuilding the Indonesian economic system based on the values of justice, solidarity, equity and benefits that refers to the Islamic law. Since then, Islamic banking is born from the womb of the Muslims became known by the Muslim and non- Muslim community so that today many conventional banks that have a special unit of Islamic banks (Ulfa, 2014) Uniqueness is what proves that Islamic banking is not just an alternative to conventional 
banking, but the solution in rebuilding the Indonesian economic system based on the values of justice, solidarity, equity and benefits that refers to the Islamic law. Since then, Islamic banking is born from the womb of the Muslims became known by the Muslim and non- Muslim community so that today many conventional banks that have a special unit of Islamic banks. Uniqueness is what proves that Islamic banking is not just an alternative to conventional banking, but the solution in rebuilding the Indonesian economic system based on the values of justice, solidarity, equity and benefits that refers to the Islamic law. Since then, Islamic banking is born from the womb of the Muslims became known by the Muslim and non- Muslim community so that today many conventional banks that have a special unit of Islamic banks (Ulfa, 2014).

The global economic crisis in 2008 and 2010 have an impact on conventional banking in Indonesia, the phenomenon of the crisis impact on the scarcity of liquidity in financial institutions (banks) led to declining public confidence in making investments and transactions. Therefore, amid the economic crisis of the Islamic banking system implemented able to withstand the economic crisis occurred. As an intermediary institution, the Bank acts collect funds from the public and to channel back to the community in the form of distribution of funds or financing.

Based on data from Bank Indonesia, the following is a general description of the data on Financing, Non Performing Financing, Islamic banking assets and Bank Indonesia Certificates Sharia that occurred in the period 2010 - 2013 is as follows:

Table 1. Composition Financing, Non Performing Financing, Islamic Banking Assets and Bank Indonesia Certificates Sharia Period 2010-2013

\begin{tabular}{ccccc}
\hline Year & $\begin{array}{c}\text { Financing } \\
\text { billion rupiah }\end{array}$ & $\begin{array}{c}\text { NPF } \\
\text { Percent }\end{array}$ & $\begin{array}{c}\text { Asset } \\
\text { billion rupiah }\end{array}$ & $\begin{array}{c}\text { SBIS } \\
\text { billion }\end{array}$ \\
\hline 2010 & 68181 & 3.02 & 97519 & 5408 \\
\hline 2011 & 102655 & 2.52 & 145467 & 9244 \\
\hline 2012 & 147505 & 2,22 & 195018 & 4993 \\
\hline 2013 & 184122 & 2.62 & 242276 & 6,699 \\
\hline \multicolumn{5}{c}{ Source: Bank Indonesia (processed) } \\
\end{tabular}

Fluctuations in Table 1. Composition of Islamic Banking Financing is inseparable from their Islamic banking assets as well as the role of monetary policy in the form of certificates of Bank Indonesia Sharia in Indonesia macro-economic developments in the period 2010-2013.

The movement of Islamic banking financing is not out of some of the indicators that influence ie Non Performing Financing (NPF), assets of Islamic Banking and Bank Indonesia Certificates Sharia (SBIS). If the note in Table 1.1 that the increase in Islamic banking financing of 2010-2013 was followed by an increase in assets owned by Islamic bank.

Although every year the value of the certificate of Indonesian Islamic banks and nonperforming financing experienced ups and downs but the assets of Islamic banking has good development. This has led to financing in Islamic banking products has increased gradually, but the real development of Islamic banking is very slow the stages because the customer is still taken of profit. 


\section{B. METHODS}

In this article, researchers used a qualitative descriptive method. Qualitative descriptive method because the data collected on this article in the form of words or images of the figure. The main objective of qualitative research is to understand the phenomenon or a social phenomenon with more focused on the complete picture of the phenomenon under study than develop them into variables are interrelated. The hope is acquired a deep understanding of the phenomenon to next produced a theory. Because the goal is different from the quantitative, then the data acquisition procedures and also different types of qualitative research (H. Mudjia Rahardjo, 2010).

Descriptive method is a method of measuring the health of humans or objects is called an event. This method examines the events that are being talked about or is happening in the present. The goal of this method is that describe or depict which is derived from the description presented systematically boosted with facts, characteristics and relationships between phenomena studied (Nazir, 2004).

Meanwhile, according Sugiyono (Sugiyono, 2013), states that a qualitative descriptive method is a method to help analyze and describe an event without making broad conclusions without data found. The conclusion must be in accordance with existing data.

He also found that applying a qualitative researcher's viewpoint trying interpretation events and social events in accordance with the viewpoint of the object of research. In qualitative research, the researcher itself acts as a research instrument; which as a research instrument researchers must have the provision of theory and extensive knowledge, so as to inquire, analyze, photograph and construct social situation under study becomes more clear and meaningful (Sugiyono, 2015).

Based on the above it can be concluded that the qualitative descriptive research is research that describe, describe, and explain the events that are applicable to the facts investigated.

The methods used in data collection for this research are as follows: 1) Library Research, The data used in this study are the data obtained from reading the literature, books, journals and the like related to the aspects studied in an attempt to obtain valid data. 2) Internet Research, Sometimes books or literature references which we have or borrow at the library for some time lags or expired (scientific), because science is always evolving. Therefore, in anticipation that the author conducted research with the technology is also evolving internet so that the data obtained is the data corresponding to the times.

\section{RESULT AND DISCUSSION}

\section{History of Islamic Banking}

Banking is an organization that conducts three main functions, which accept deposits, lend money, and provide money transfer services. In the economic history of the Muslims, the financing is done by contract Shariah compliance have become part of the tradition of the Muslims since the time of Prophet Muhammad. Such practices treasure receives deposits, lend money for consumption purposes and business purposes, as well as transferring money, has been prevalent since the time of Prophet Muhammad. Thus, the main functions of modern banking that accept deposits, transfer funds, and transfer funds have become an integral part of the lives of Muslims, even since the time of the Prophet.

Based on the history of emergence, Islamic banks are generally known as known as the Islamic bank. Islamic bank then it undergoes three stages of development. The first phase, the 
period of the emergence of large banks and liquidity in the Middle East. This period is the peak of the Muslim community awareness to develop Islamic financial institutions.

Local operation of Mit Ghamr Savings Bank in Egypt in 1963 marked a milestone in the development of the Islamic banking system. In 1967 the operation of the Mit Ghamr Savings Bank Local taken by the National Bank of Egypt and the Central Bank of Egypt due to political turmoil. Jordan Islamic Bank stood at Jordan and then followed by the establishment of Nasser Social Bank in Egypt. In 1975 the IDB also stood (Islamic Development Bank) and Dubai Islamic Bank in Saudi Arabia, established on the initiative of foreign ministers session in the session which proposed the abolition of the financial system is based on interest and replace it with a system of revenue sharing. The second stage, the development period in 1976 until the early 1980s, marked by the banking spread from Asia to the Arabian Gulf region (east) and later to Europe (West). In the third stage, a period in which Islamic banking has progressed at around 1983 to the present. In 1983 in Malaysia stood Bank Islam Malaysia Berhad and then followed by the establishment of the Financial Institutions Investment repair company (Al Rajhi) in Saudi Arabia and Al-Barakah Turkish Finance House in Turkey in 1985.

The development of Islamic banks in the countries of Islamic influence to Indonesia early period of the 1980s has been much discussion about Islamic Bank as Islam. New economic pillar started in 1990. (Adiwarman Karim, 2010)

a. The development of Islamic Banking in Indonesia

Bank is a financial intermediary is generally established with the authority to raise and channel public savings back to the community. According to the Law of the Republic of Indonesia Number 10 of 1998 November 10, 1998 on the banks, which meant the bank is "business entities that raise funds from the public in the form of savings and distributed to society in the form of credit or other forms of others in order to improve the living standard of the people ".

Beginning in the 1980s, discussion about Islamic economy started. Even the relatively limited trials have been conducted, including the Baitul Mal Wa Cooperative Tamwil Salman Bandung and Jakarta Ridho Gusti. More specifically initiative for the establishment of a new Islamic bank began in 1990. MUNAS IV MUI (Indonesian Ulema Council) in August 1990 established a working group to establish the Bank Muamalat (Antonio et al., 2012).

Establishment of Islamic bank in Indonesia started since 1998, when the government issued October Policy Package (Pakto) governing the deregulation of the banking industry in Indonesia. The scholars have tried to set up an interest-free bank, but none of the laws that exist that banks may be set at 0 percentage interest (Zainul Arifin, 2002).

Soemitra (Soemitra, 2009) in 1998 out of Law No. 10 of 1998 on the amendment of Law No. 71992 which recognizes the existence of Islamic Banking and Conventional Banks as well as introducing a Conventional Bank opened a branch office of sharia. Until the year 2008 concerning Islamic Banking was passed which provided the legal foundation and the national Islamic banking industry is expected to encourage the development of Islamic banks during the last five years of its assets grow 65\% per year, but the market (market share) nationally is still below 5\%. Legislation specifically on Islamic banking, both institutionally and business activities. Some agencies new law introduced by Law No. $21 / 2008$, among others, which involves the separation (spin-off) UUS voluntary and mandatory and Islamic Banking Committee. There are several PBI (Bank Indonesia Regulation), which is particularly significant in the implementing regulations of Law No. 21 of 2008 concerning Islamic Banking and has been enacted to date include: 
1) PBI 10/16 / PBI / 2008 on Amendment to PBI 9/19 / PBI / 2007 regarding Sharia Implementation in Fund Raising Activities and Funds Distribution and Islamic Banking Services. Legal device irrevocable unless their interpretation

2) PBI 10/17 / PBI / 2008 on Islamic Banking products and Sharia.

3) PBI No.10 / 18 / PBI / 2008 on Restructuring Financing for Sharia Banks.

4) PBI 10/23 / PBI / 2008 regarding the Second Amendment to PBI 6/21 / PBI / 2004 on Statutory Reserves and Foreign Currency IDR Performance for Commercial Banks Conducting Business Based on Sharia Principles.

5) PBI 10/24 / PBI / 2008 regarding the Second Amendment to PBI 8/21 / PBI / 2006 regarding Asset Quality Rating for Commercial Banks Conducting Business Based on Sharia Principles.

6) PBI 10/32 / PBI / 2008 regarding Sharia Banking Committee.

7) PBI 11/3 / PBI / 2009 on Islamic Banks.

Now the Islamic Banking has been progressing Islamic Banking of Bank Indonesia, the growth of Islamic banks today shows the amount of public demand for Islamic banking services. This is reflected in a significant growth in the number of banks from the office network of Islamic banking and financial performance during the year 2011, the number of banks conducting business based on sharia principles increased.

Islamic banking conditions in the coming year is expected to continue to improve. This is evident from the high public interest in Islamic banking. In order to increase reach through easy to open a service office, is expected to give effect to the public interest. On the other hand, in International opportunities utilizing foreign investment, particularly from the Middle East to the Indonesian economy system is still wide open.

b. Financing the development of Islamic Banking

Financing or financing, is financing provided by one party to the other to support the planned investment, either by themselves or institution. In other words, the financing is funding incurred to support the planned investment (Ade, 2009).

According to Law No. 10 of 1998 (Article 1) states that, "Financing based on Islamic principles is the provision of cash or the equivalent based on agreements between the bank and other parties who require the financed party to return the money or bills after a certain period in exchange or for the results ". The development of Islamic banking financing period January 2010 to December 2013 can be seen from the following picture: 
Figure 1. Financing the development of Islamic Banking in Indonesia period January 2010 - December 2013

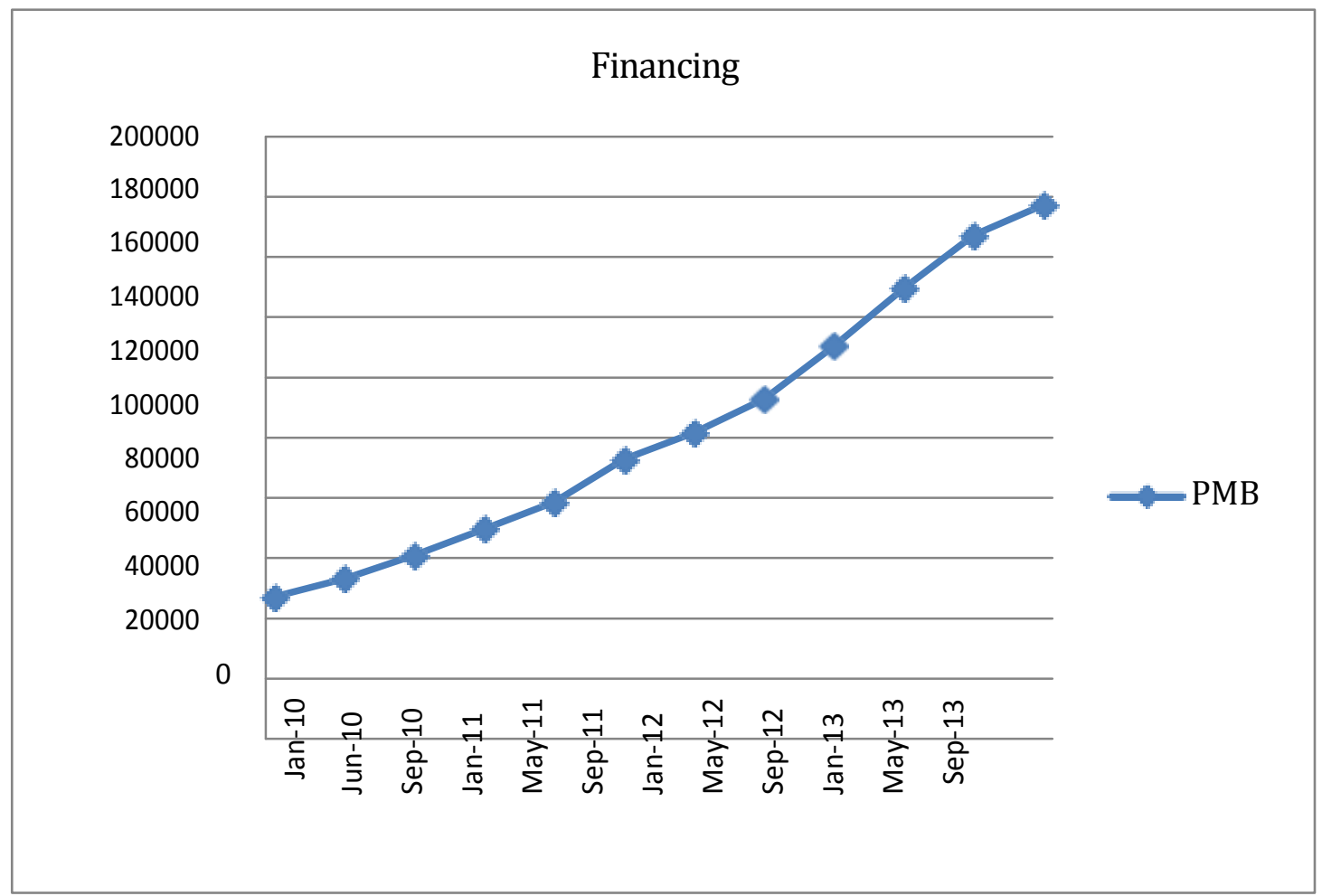

Macro-economic conditions conducive and national banking industry sector performance remained positive that one of the factors supporting the growth of Islamic banking financing during late 2009 and early 2010. In 2010 the Islamic banking financing reached IDR68 181 billion. With a growth rate in terms of funding and financing were relatively similar, Islamic banking intermediation function, among others represented by Financing to Deposit Ratio (FDR) did not experience a lot of changes compared to the previous year.

In 2013 financing of growth than in previous years. It can be seen in the financing committed by Islamic banking reached Rp 184122 billion. It shows that the financing is still the main choice of fund placement Islamic banking compared to other placements like placement on $\mathrm{BI}$, other banks or securities.

From a number of financing products offered, financing Murabaha (sale and purchase) the most dominating. Compared with the number of Musharaka and Mudaraba financing. Murabaha financing product is desirable given its characteristics less risky, easier to implement and more oriented towards short-term financing so for Islamic banking is currently experiencing growth, it is preferred.

c. The development of Non Performing Financing (NPF)

Non Performing Financing (NPF) is the ratio between the troubled financing with total financing provided by Islamic banks. Based on the criteria set by Bank Indonesia categories included in the NPF is financing substandard, doubtful and loss. Below is a picture of the development of Non Performing Financing (NPF) in Indonesia from January 2010 until December 2013. 
Figure 2. The development of Non Performing Financing (NPF) in Indonesia during the period January 2010 - December 2013

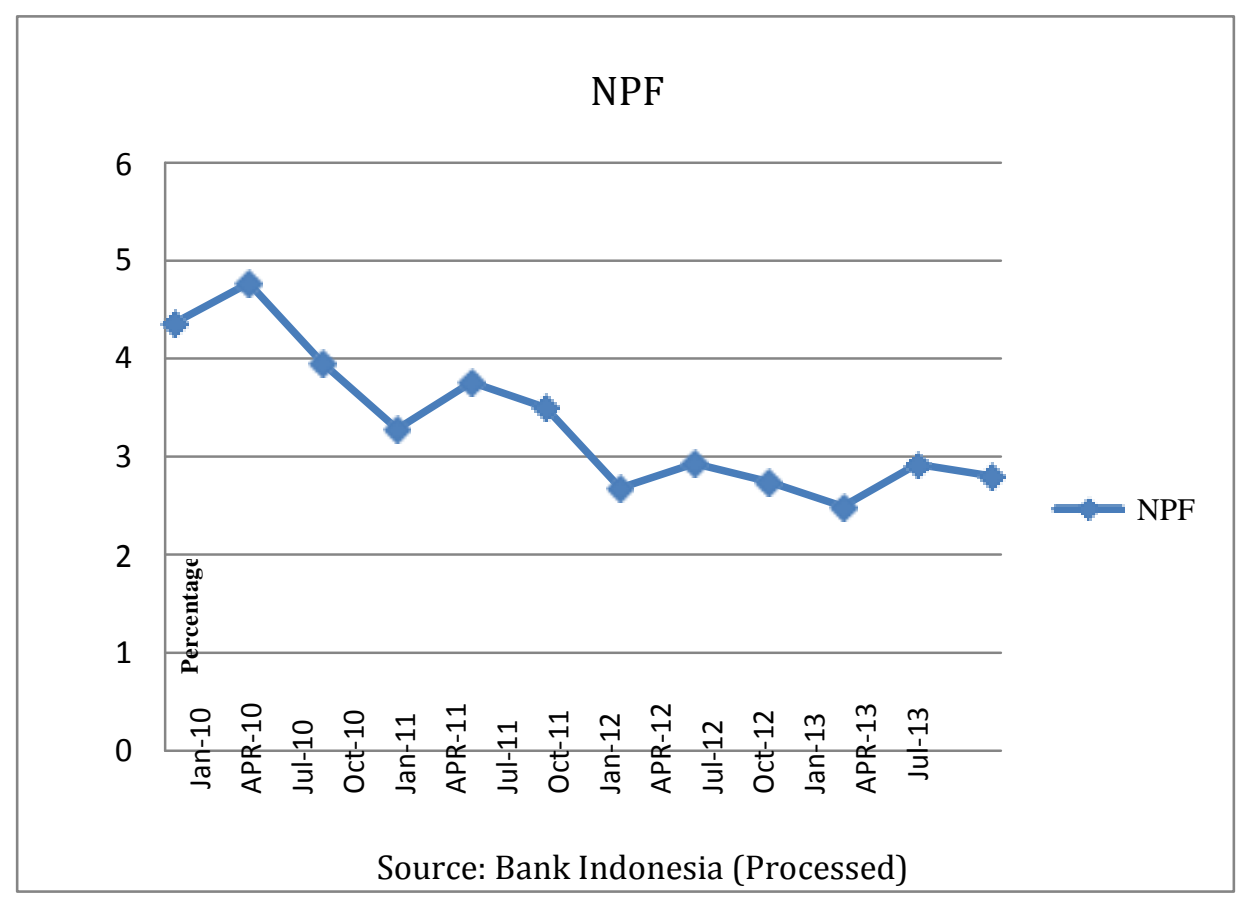

Non-current financing is a thing that is always found in every activity of Islamic financial institutions. Non-current financing is not a thing to be avoided, because each customer conduct their economic activities with the conditions and the level of success is different.

The value of non-current financing large enough happened in April 2010 to reach 4.47 percentage and lowest in December 2012 reached 2.22 percent to the total finance portfolio reached USD 53223 billion. If the figures were calculated based on the formula of determining the ratio of the value of the NPF to the total funding channeled that the resulting figure is classified to the category NPF safe category. Based on these values, it can be explained that in nominal terms, the NPF is very likely to increase in line with the increase in the nominal amount of financing provided. This suggests that any risk of noncurrent financing of finding financing, if you want to improve financing to the public, which are categorized as non-normally financing is very likely to increase.

Based on the above explanation, it can be concluded that the non-current financing Islamic bank in Indonesia fluctuated quite visible as depicted in the curve above. However, the development of non-current financing Islamic bank in Indonesia still controlled figure shows (below 5\%). In other words, the non-current financing Islamic bank in Indonesia shows the performance of a controlled and not a measure that led to the bank becomes unhealthy conditions so far.

d. The development of Islamic Banking Assets

Assets (assets) Commercial Bank in the balance sheet are classified into four main groups namely reserves, consisting of collateral and cash to the needs of customer transactions, credit (loans / financing), investment securities (security investment) and other assets in the form of fixed assets consisting of top land and buildings as well as office equipment. Below is a picture of the development of Islamic banking assets in Indonesia in the period January 2010 to December 2013. 
Figure 3. Development of Banking Assets Sharia in Indonesia period January 2010 - December 2013

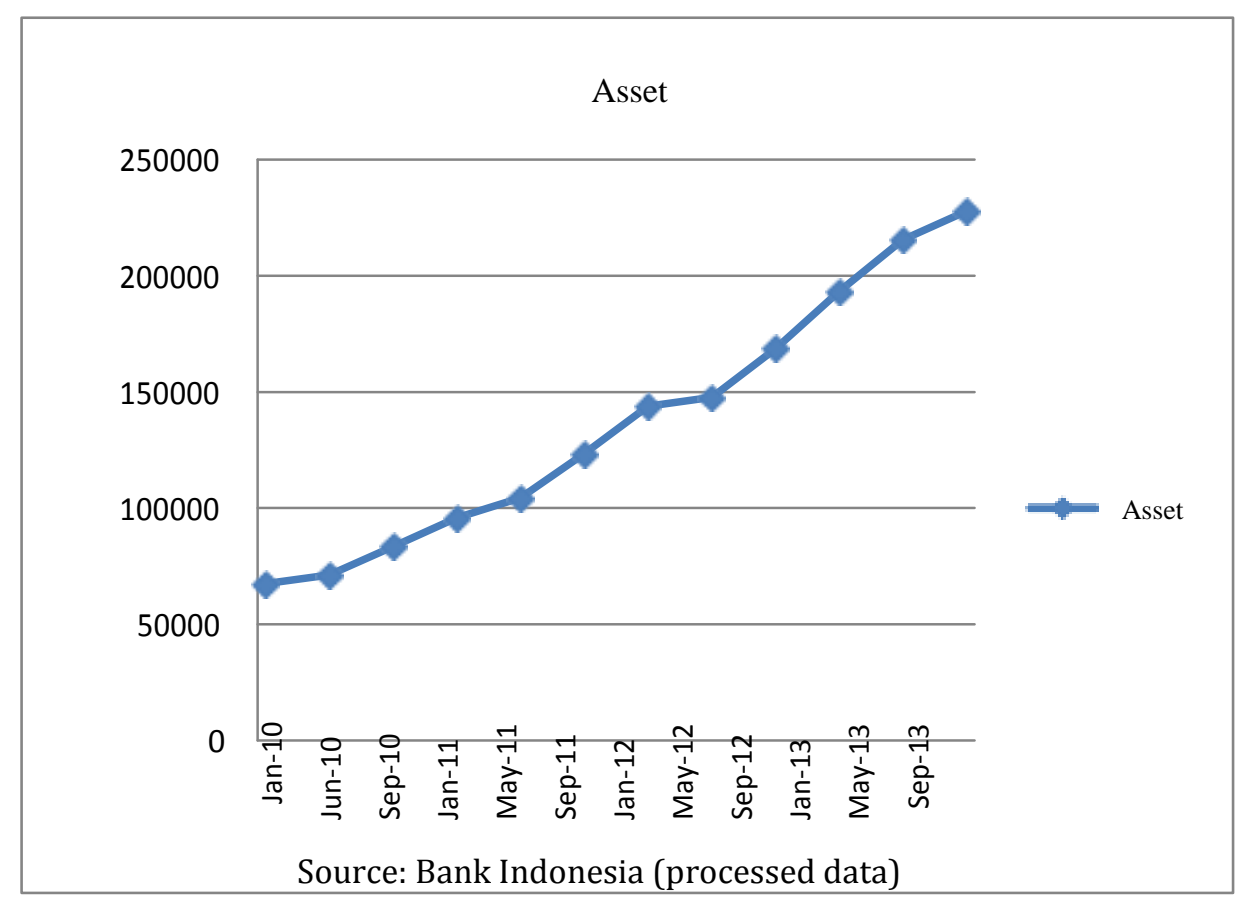

Can be seen from Figure 3. above the asset development in general Islamic banks in Indonesia continues to increase every year. This indicates a positive indication that in terms of progress towards achieving the vision of development set by Bank Indonesia. So that the acceleration of growth in assets of Islamic banks will be easier to achieve. Then the development of stable asset with a consistent pattern of rise shows the development of Islamic bank assets is an advantage for the performance of Islamic banks in Indonesia.

Performance of Islamic banking is gaining momentum acceleration in the year 2010 in which Islamic banking assets increased significantly with the growth reached IDR97,519 billion. The increase was partly driven by the establishment of a number of Islamic Banks (BUS) and the new Islamic banking office network. In line with the good performance of the economy, the stability of the financial system in 2012 will be maintained, and the banking sector in general is still able to maintain the positive performance reflected in the increased intermediation, improved efficiency, and resilience in the face of crisis.

Throughout the year 2012 the total assets of commercial banks grew by IDR195.018 billion. One of them was driven by the expansion of credit Commercial Bank (BUK), which reached IDR507.8 trillion, or 23.1\%.Although a bit slow compared to credit growth in 2011 of $24.6 \%$, the general function of banking intermediation is still showing an increase as more and the contribution of credit to the productive sectors in the form of credit for investment and working capital (70.5\%, from the previous year $69,7 \%)$, lending more affordable (average decreased $68 \mathrm{bps}$ from a year ago), and LDR were further improved to $83.6 \%$, from the prior year by $78.8 \%$. The efficiency of banks in the reporting period.

In 2013 the total assets of Islamic banking in March 2013 reached IDR209,603 billion, or $4.8 \%$ of the total assets of the national banking assets. In August 2013 the value of assets reached IDR223,503 billion, and in December reached IDR242,276 billion, up 50\% from the year ago period. This is partly driven by the improved performance of the real sector and 
the activities of the Islamic banking industry is increasing. In addition to the start of expansion of new Islamic Banks were standing in the previous year.

e. The development of Bank Indonesia Certificates Sharia (SBIS)

In practice, Islamic banks as a mediator can be deficient or excess liquidity caused by the time difference (time lag) between the time of receipt and the planting of liquidity. To deal with the excess liquidity and money supply Islamic bank, Bank Indonesia issued a monetary policy open market that Bank Indonesia Certificates Sharia (SBIS).

Certificate Bank Indonesia Sharia (SBIS) are securities issued by Bank Indonesia in recognition of short-term debt. With bonus system, SBIS is one mechanism used by Bank Indonesia to control the stability of the rupiah. By selling SBIS, Bank Indonesia will be able to absorb the excess base money in circulation. Therefore SBIS values always fluctuate. Certificate development Bank Indonesia Sharia (SBIS) in the period January 2010 to December 2013 can be seen from the following picture:

Figure 4. Certificate development Bank Indonesia Sharia (SBIS) In Indonesia the period January 2010 December 2013

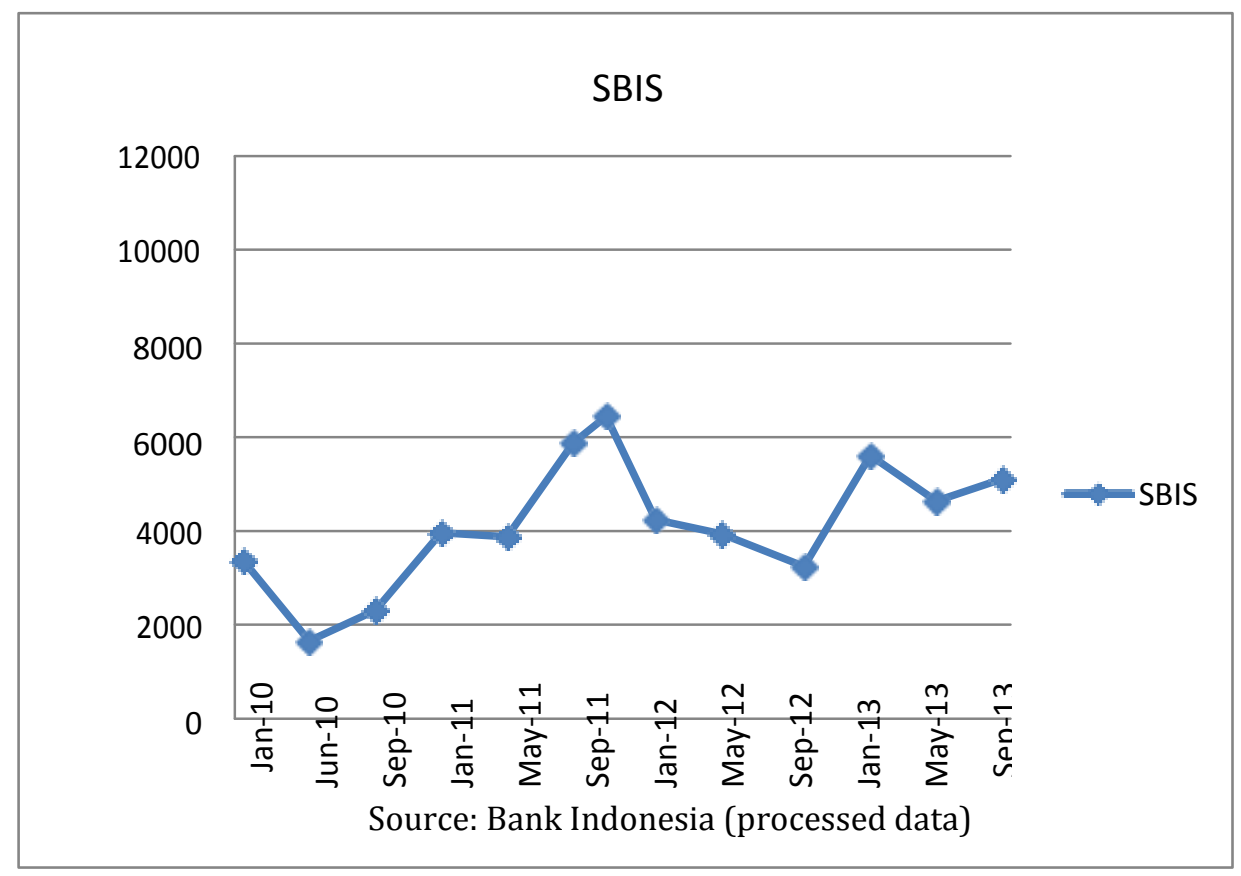

\section{Discussion Economic Analysis}

From the results of multiple regression analysis showed that three variables of Non Performing Financing (NPF), the assets of Islamic banking, Bank Indonesia Certificates Sharia (SBIS) against the Islamic banking financing was not all significant independent variables, which have a significant effect only variable assets and SBIS. This means that the financing of Islamic Banking in Islamic Banking is only affected by some of the independent variables tested.

Non-performing financing is a risk that must be borne by the banks in disbursing funds in the form of financing. One way to minimize the NPF. With the precautionary principle which is a guideline Islamic banks to reduce financing problems. Precautions for fund distribution is done of Islamic banks to fund distributed to customers / community can be used as is and can generate the expected profits.

In this study from January 2010 to December 2013 NPF variables showed no significant effect relationships and negative. This is in line with previous research conducted by Wuri and Harjum (Ikhsan \& Muharam, 2016). With a negative direction means that the higher the level of non-performing financing (NPF) in Islamic banks will lower the financing in Islamic banks. 
This occurs because the non-performing financing or non-performing loans will increase costs, so that in the future will potentially against bank losses. The higher this ratio the more worse the quality of bank financing which led to the non-current loan amount and therefore the greater the Islamic banks should bear the losses in its operations and therefore contributes to the decline of Islamic bank financing.

However, in this study that NPF did not affect the Islamic banking financing. This is because the percentage of NPF in that period is still relatively small range below the Bank Indonesia Sharia standards for Islamic banks 5\% so not too experienced a shock because of the NPF. Plus the tendency of customers to pay on time are greater and supported by the amount of third party funds received by the bank. So the percentage of NPF period 2010 to 2013 no influence the distribution of funding granted Islamic banking.

Islamic banks can reduce the amount of margin charged by the customer. Handling of financing problems, especially the financing of doubtful / jammed by Islamic banks more in a way that is far reconditioning profit margins or results of operations of Islamic bank. For the refund of goods can be returned quickly and smoothly without having to think about the margin set / agreed between the Islamic banks and Islamic banks own customers (Haris, 2015).

In this study that the asset has positive and significant effect on the financing of Islamic Banking. Wherein when the value of assets increases, will increase Perbanakan Financing the Sharia. Conversely, if the assets are declining, will reduce the level of financing Islamic Perbanakan owned by the Islamic Banking.

In line with previous research Lailiatul Maturoh (Lailiatul Masturoh, 2009) which states that the reciprocal relationship (feedback) between the variables of total assets, with the financing variables. Variables significantly financing has a great influence on the variable financing in Islamic banking in Indonesia, it is reflected by the growing strength of capital, reduced credit risk, and increasing the profitability of banks.

Islamic Banking assets from the period January 2010 to December 2013 grew. The tendency of increase in assets due to macro growth of the national economy has good development and micro-network of offices Islamic banks and Islamic business units significantly increased as the implications of the emergence of new Islamic banks. So that the funding provided by the Islamic banking also increased high enough for easy access to customer / community to transact in Islamic banking.

In addition, public education activities are being conducted in order to introduce products and advantages of Islamic banking system is increasingly able to attract new customers. Banking in general is still able to maintain a positive performance accompanied by a continued increase in the intermediation function.

Bank Indonesia Certificates Sharia (SBIS) is also one of the variables researched in this study. This variable significant and adversely affect funding channeled Islamic banking and in line with research conducted by Widyastuti and Anwar impact caused by the Islamic monetary instruments to the performance of Islamic banking will decrease (change) financing (Kusumawati, 2013).

These instruments are used for the processing of sharia bank liquidity. If there is a surplus of funds in the Islamic banks Islamic banks to place funds on SBIS Islamic banking. Placement is an indication of price signals not properly Islamic banking financing and optimal. Islamic banking so look for alternatives to invest in the existing Islamic monetary instrument.

By placing the excess over the amount of funds on Islamic monetary instrument, namely SBIS have more impact and minimal risk to the performance of Islamic banking compared to other Islamic monetary instrument. This is done so that there are no funds idle (idle funds) to fund the Islamic banking can be optimally channeled. Because Islam strongly recommends that property investment activity to be useful and more productive so as to bring benefits.

In practice, the distribution of funds of Islamic banks to the real sector which often do not require the shortest time union funds, therefore, Islamic banks location excess funds from third party funds SBIS though only promise a bonus but it is quite safe and flexible. Funds invested over a number of Islamic banks in the SBIS will get a bonus which is an advantage for Islamic 
banks. Thus the larger the bonus resulting from SBIS, it will be more attractive for Islamic banking to keep their funds in SBIS thereby decreasing the amount of financing provided by Islamic banks.

According to the book Arifin (Zainul Arifin, 2002). If Islamic banks have excess funds at the level of the excess liquidity then the funds can be deposited to Bank Indonesia in its monetary operations through the issuance of SBIS announced a target of liquidity to the application of Islamic banks as monetary control efforts and promising rewards (reward / 'iwadh, ju'i ) from Bank Indonesia to Islamic banking. So if high DPK Islamic banks, Islamic banks can deposit the funds to instruments SBIS.

\section{CONCLUSION AND SUGGESTIONS}

Based on the results of data processing of the research entitled "Analysis of Effect of Non Performing Financing (NPF), assets of Islamic Banking and Bank Indonesia Certificates Sharia (SBIS) on the financing of Islamic Banking in Indonesia period January 2010 - December 2013".

Based on the results of OLS regression (Ordinary Least Square) from this study can be summarized Simultaneously variable Non Performing Financing (NPF), assets of Islamic Banking and Bank Indonesia Certificates Sharia (SBIS) jointly have a significant effect on the financing of Islamic banking in Indonesia.

Individually (partially) the results of this study as follows: (a) Variable Non Performing Financing (NPF) do not significantly and adversely financing. This means that any increase in the NPF will lower the financing. Where t count equal to -0.054428 with a significant level of 0.9568 . (b) Islamic Banking Asset Variable significant influence and positive impact on financing. This means that any increase in the asset will increase the financing. Where t count equal to 5.166142 with a significant level of 0.0000. (c) Variable Bank Indonesia Certificates Sharia (SBIS) significantly and negatively to financing. This means that any increase in SBIS it will lower the financing. Where SBIS $t$ value of -2.051611 and significance level is 0.0463 .

Adjusted R-squared of 0.379406 suggesting that variations in the dependent variable (Financing) jointly able to be explained by variations in the independent variable (NPF, ASSET and SBIS) amounted to 37.94 per cent while the remaining 62.06 percent is explained by other variables outside variables studied.

\section{REFERENCES}

Ade, M. (2009). Ekonomi Syariah: Peluang dan Tantangan Bagi Ekonomi Indonesia. Al-Iqtishad: Jurnal Ilmu Ekonomi Syariah, 1(1). https://doi.org/10.15408/aiq.v1i1.2457

Adiwarman Karim. (2010). Ekonomi Makro Islami. PT Raja Grafindo Persada.

Antonio, M. S., Sanrego, Y. D., \& Taufiq, M. (2012). IIUM Institute of Islamic Banking and Finance ISSN. In Journal of Islamic Finance (Vol. 1, Issue 1). https://platform.almanhal.com/Files/2/37299

H. Mudjia Rahardjo. (2010). Triangulasi dalam Penelitian Kualitatif. Universitas Islam Negeri Maulana Malik Ibrahim Malang. https://doi.org/10.1360/zd-2013-43-6-1064

HARIS, M. (2015). Analisis faktor-faktor yang memengaruhi preferensi nasabah terhadap bank syariah di dki jakarta. Jurnal Ilmiah Mahasiswa IPB, 11-39.

Ikhsan, A. A., \& Muharam, H. (2016). Pengaruh Kinerja Lingkungan Terhadap Kinerja Keuangan : Studi Pada Perusahaan yang Terdaftar Di Kementrian Lingkungan Hidup Dan Listing Di BEI. Diponegoro Journal of Management, 5(3), 1-11.

Kusumawati, N. N. (2013). Analisis Pembiayaan Sektor Konstruksi Pada Perbankan Syariah di Indonesia Islamic Banking Financing Analysis on Construction Sector in Indonesia. Jurnal Al-Muzara'ah, I(2), 191-203.

Lailiatul Masturoh. (2009). Analisis Hubungan Total Aset Dan Pembiayaan Pada Perbankan Syariah Di Indonesia (Periode 2004:1-2007:12) [Universitas Airlangga]. 
http://repository.unair.ac.id/id/eprint/7999

Nazir. (2004). Metode Penelitian. Metode Penelitian, 5, 231.

Soemitra, A. (2009). Bank dan lembaga Keuangan Syariah. Kencana, 26-54.

Sugiyono. (2013). Buku - Sugiyono. In Metode Penelitian Kuantitatif, Kualitatif, dan R \& D (p. 407).

Sugiyono. (2015). Metode Penelitian. Metode Penelitian, 1-32.

Ulfa, M. (2014). Pengaruh Modal Intelektual terhadap Nilai Perusahaan dan Kinerja Keuangan pada Perusahaan Perbankan yang Terdaftar di BEI Tahun 2008-2011. Artikel Ilmiah Mahasiswa STIE Perbanas Surabaya.

Zainul Arifin. (2002). Dasar-Dasar Manajemen Bank Syariah. Azkia Publisher. 